| Konflik Agraria yang Tak Kunjung Usai

\title{
KONFLIK AGRARIA YANG TAK KUNJUNG USAI
}

\author{
Poerwanti Hadi Pratiwi 1
}

\begin{abstract}
Abstraksi
Konflik agraria yang terjadi di Tawangmangu antara Pemerintah Provinsi Jawa Tengah dengan penduduk Tawangmangu pemilik tanah persil belum juga menemui jalan keluar meskipun sudah berlangsung sejak tahun 1986. Resolusi konflik yang ditawarkan oleh Pemerintah Provinsi Jawa Tengah belum mencerminkan rasa keadilan. Hukum agraria yang ada dan menjadi dasar pemerintah menyelesaikan konflik tersebut merupakan keputusan sepihak Pemerintah yang jauh dari rasa keadilan, karena tidak mempertimbangkan partisipasi penduduk Tawangmangu pemilik tanah persil dalam proses resolusi konflik. Dengan demikian, konflik belum selesai dan tidak menutup kemungkinan di kemudian hari penduduk Tawangmangu pemilik tanah persil kembali melakukan berbagai protes-protes agraria guna menuntut resolusi konflik yang berbasis pada rasa keadilan.
\end{abstract}

Kata Kunci: Konflik Agraria, Tanah Persil, Resolusi Konflik

\footnotetext{
${ }^{1}$ Dosen pada Program Studi Pendidikan Sosiologi FISE UNY.
} 


\section{A. Pendahuluan}

Berdasarkan hasil penelitian Poerwanti Hadi Pratiwi (2007), tanah persil di Tawangmangu menjadi masalah pelik bagi penduduk Tawangmangu karena hingga sekarang belum memperoleh kepastian hukum. Ada beberapa kesimpulan yang dapat ditarik dari studi ini, yaitu: 1) sengketa agraria bersumber pada penyebab struktural, yaitu kebijakan pertanahan warisan Orde Baru, yang pada masa reformasi sekarang masih tetap dijalankan oleh aparat Pemerintah; 2) isu utama yang dikembangkan dalam sengketa agraria di Tawangmangu adalah perebutan sumber daya agraria berupa tanah persil antara masyarakat Tawangmangu pemilik tanah persil dengan Pemerintah Provinsi Jawa Tengah melalui Perusahaan Pariwisata Tawangmangu (PPT) dan isu sekunder yang berhubungan dengan aspek ekonomi, yaitu penjualan tanah persil untuk meningkatkan Pendapatan Asli Daerah (PAD) Pemerintah Provinsi Jawa Tengah; 3) pihak yang terlibat langsung dalam sengketa agraria adalah masyarakat Tawangmangu pemilik tanah persil dengan Pemerintah Provinsi Jawa Tengah melalui Perusahaan Pariwisata Tawangmangu (PPT), sedangkan pihak yang terlibat tidak langsung adalah LSM dan Pemerintah Kabupaten Karanganyar.

Dalam penelitian tersebut juga dipaparkan bahwa setelah berlarut-larutnya penyelesaian konflik tanah persil di Tawangmangu, akhirnya pada tanggal 27 Februari 2007 DPRD Jawa Tengah mengadakan Rapat Paripurna yang membahas tentang pelepasan/ penjualan tanah persil Tawangmangu dengan kompensasi harga. Tentu saja "pelepasan/ penjualan tanah persil" ini dianggap sebagai resolusi konflik terbaik yang dipilih oleh DPRD dan Pemerintah Provinsi Jawa Tengah, karena hal ini justru dapat menguntungkan Pemerintah Provinsi Jawa Tengah. Sebenarnya resolusi konflik yang dihasilkan merupakan keputusan sepihak dan sangat merugikan penduduk Tawangmangu pemilik tanah persil.

Surat Keputusan DPRD Jawa Tengah Nomor: 12 Tahun 2007 tentang Penjualan/ Pelepasan Tanah Persil Tawangmangu dengan Kompensasi merupakan keputusan yang tidak berpihak kepada penduduk Tawangmangu pemilik tanah persil karena penduduk harus membayarkan sejumlah uang kepada Pemerintah Provinsi Jawa Tengah melalui Perusahaan Pariwisata Tawangmangu (PPT) untuk memperoleh sertifikat hak milik atas tanah persil tersebut. Berdasarkan hasil Rapat Paripurna DPRD Jawa Tengah, maka uang yang harus dibayarkan adalah sebesar Rp 369.078.841.000,- untuk membebaskan tanah seluas 682.220 $\mathrm{m}^{2}$. Setelah dilakukan perhitungan lebih lanjut, maka setiap Kepala Keluarga pemilik tanah persil harus membayar uang sejumlah $\mathrm{Rp}$ 192.984.620,-. Uang senilai itu telah mengalami penurunan harga sebesar $70 \%$. Berikut ini akan disajikan hasil Rapat Paripurna DPRD Jawa Tengah tentang 
Konflik Agraria yang Tak Kunjung Usai

pelepasan tanah persil di Tawangmangu.

Tabel 1.

Hasil Rapat Paripurna DPRD Jawa Tengah

Tentang Pelepasan Tanah Persil Tawangmangu

\begin{tabular}{|c|c|c|c|c|c|}
\hline No. & Kategori & Jumlah & $\begin{array}{l}\text { Luas } \\
\text { Tanah }\end{array}$ & $\begin{array}{c}\text { Kompensasi } \\
\text { Harga }\end{array}$ & $\begin{array}{c}\text { Penurunan } \\
\text { Harga }\end{array}$ \\
\hline 1. & Hotel/ pondok & 12 & $6.169 \mathrm{~m}^{2}$ & Rp $\quad 4,30$ miliar & $10 \%$ \\
\hline 2. & Villa & 268 & $455.914 \mathrm{~m}^{2}$ & $\operatorname{Rp} 267,26$ miliar & $10 \%$ \\
\hline 3. & Rekreasi & 3 & $71.077 \mathrm{~m}^{2}$ & Rp 35,53 miliar & $10 \%$ \\
\hline 4. & $\begin{array}{l}\text { Rumah } \\
\text { makan/toko }\end{array}$ & 24 & $11.568 \mathrm{~m}^{2}$ & Rp $\quad 6,82$ miliar & $10 \%$ \\
\hline 5. & Instansi & 9 & $25.703 \mathrm{~m}^{2}$ & 7,64 miliar & $10 \%$ \\
\hline 6. & Rumah tangga & 65 & $50.146 \mathrm{~m}^{2}$ & Rp 17,92 miliar & $70 \%$ \\
\hline 7. & Pertanian & 3 & $14.926 \mathrm{~m}^{2}$ & Rp $\quad 2,55$ miliar & $10 \%$ \\
\hline 8. & Sosial & 2 & $8.281 \mathrm{~m}^{2}$ & 4,69 miliar & $30 \%$ \\
\hline 9. & Wisma & 1 & $8.436 \mathrm{~m}^{2}$ & 2,04 miliar & $10 \%$ \\
\hline
\end{tabular}

Sumber: Solo Pos (28 Februari 2007).

Tidak dilibatkannya penduduk Tawangmangu pemilik tanah persil dalam proses resolusi konflik menyebabkan mereka tidak dapat menerima keputusan yang dikeluarkan oleh DPRD Jawa Tengah dengan konsekuensi yang tidak dapat mereka tanggung. Mereka akan menghindari keputusan yang akan menimbulkan kesulitan bila mereka menerimanya. Dengan demikian dapat disimpulkan bahwa penduduk Tawangmangu pemilik tanah persil tidak puas dengan resolusi konflik yang ditawarkan oleh DPRD dan Pemerintah Provinsi Jawa Tengah. Berdasarkan tuntutan penduduk Tawangmangu pemilik tanah persil, maka resolusi konflik yang sangat mereka harapkan adalah pelepasan tanah dari Pemerintah Provinsi
Jawa Tengah tanpa kompensasi apapun (hibah tanah).

Tulisan ini selanjutnya akan mendeskripsikan perkembangan yang terjadi saat ini di Tawangmangu terkait sengketa tanah persil. Mengapa penduduk Tawangmangu tetap berkonflik dengan Pemprov Jawa Tengah dan tidak mau menjalankan keputusan yang telah ditetapkan DPRD Jawa Tengah? Alternatif solusi apa yang kemudian berusaha dijalankan Pemerintah Provinsi Jawa Tengah menghadapi penduduk pemilik tanah persil? Bagaimanakah seharusnya resolusi konflik yang memiliki keadilan bagi semua pihak? 


\section{B. Pembahasan}

\section{Konflik Atas Tanah}

Isu sentral dari konflik pertanahan yang terjadi di Tawangmangu adalah tuntutan penduduk lokal Tawangmangu atas status tanah persil yang telah dihuni dan digarap selama hampir 50 tahun menjadi hak milik penduduk. Pada tahap awal terjadinya konflik pertanahan di Tawangmangu (sekitar pasca kemerdekaan hingga masa Orde Baru), faktor penyebabnya adalah tuntutan warga Tawangmangu terhadap status kepemilikan tanah persil menjadi hak milik individu/ perorangan. Pada masa ini jelas bahwa yang menjadi lawan warga Tawangmangu adalah Negara (Pemerintah Provinsi Jawa Tengah melalui Perusahaan Pariwisata Tawangmangu/PPT), karena tanahtanah mereka diambil alih secara paksa oleh Negara melalui seritifikat HPL (Hak Pengelolaan Lahan) yang dikeluarkan BPN (Badan Pertanahan Nasional) sebagai legalitas/ dasar hukumnya. Untuk itulah, berbagai cara dilakukan oleh masyarakat Tawangmangu guna memperoleh status kepemilikan tanah-tanah mereka, salah satunya adalah dengan mendirikan organisasi pemilik tanah persil Tawangmangu yang diberi nama HPTPT (Himpunan Pemilik Tanah Persil Tawangmangu).
Menghadapi tuntutan dari
masyarakat Tawangmangu,
rupanya Pemerintah Provinsi Jawa
Tengah tidak tinggal diam dan
mengambil beberapa kebijakan
guna meredakan protes-protes yang
dilakukan oleh masyarakat
Tawangmangu.
$\begin{array}{lr}\text { masyarakat menganggap bahwa } \\ \text { kebijakan-kebijakan yang }\end{array}$ dikeluarkan oleh Pemerintah Provinsi Jawa Tengah tidak populis namun cenderung elitis sehingga merugikan masyarakat dan semakin menguntungkan Pemerintah. Dalam implementasinya, kebijakankebijakan yang dikeluarkan oleh Pemerintah Provinsi Jawa Tengah tersebut justru menimbulkan konflik intern organisasi dalam HPTPT, sehingga dalam tubuh НРТРT terbagi dalam 2 fraksi (kelompok). Warga asli Tawangmangu yang merasa dirugikan akhirnya memisahkan diri untuk kemudian membentuk organisasi sendiri dengan nama PWTPTP (Paguyuban Warga Tawangmangu Pemilik Tanah Persil).

Tidak sampai disitu saja, isu konflik pun mengalami perkembangan sesuai dengan visi dan misi yang dimiliki oleh masingmasing organisasi tersebut. Untuk lebih ringkasnya, dinamika konflik agraria di Tawangmangu dapat dilihat pada tabel berikut ini: 
Konflik Agraria yang Tak Kunjung Usai

Tabel 2.

Dinamika Konflik Tanah Persil di Tawangmangu

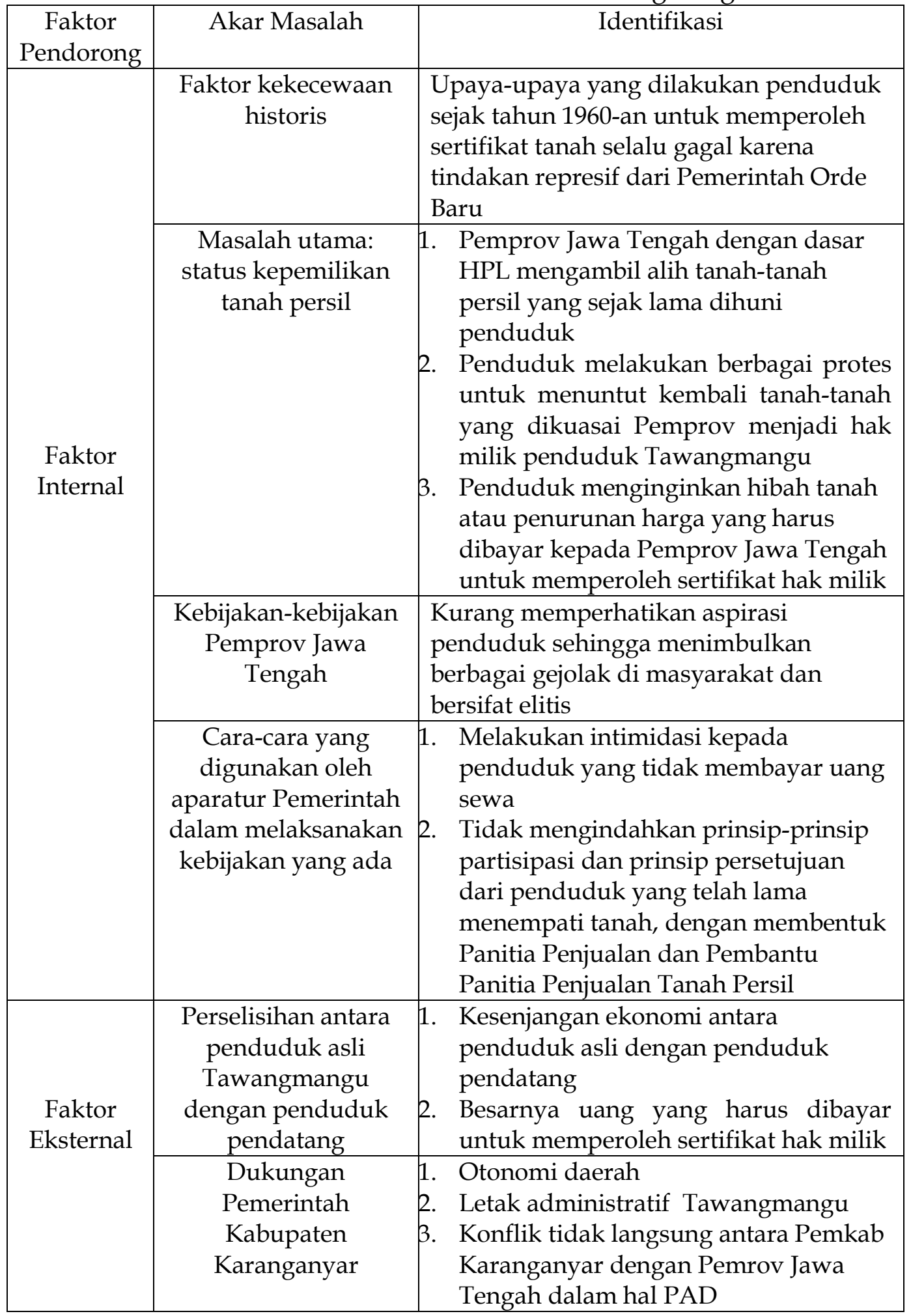

Sumber: diolah dari berbagai sumber 
Berbagai upaya telah dilakukan penduduk pemilik tanah persil Tawangmangu dalam menyelesaikan konflik dengan Pemerintah Provinsi Jawa Tengah tentang masalah status kepemilikan tanah persil. Tidak jarang mereka melakukan negosiasi sebagai cara yang dianggap paling diplomatis untuk menyelesaikan konflik ini, namun hasilnya sia-sia. Upaya warga Tawangmangu ini sempat terhenti untuk beberapa waktu terkait dengan perubahan situasi politik dalam negeri pada sekitar tahun 1998 - 1999 karena terjadi peristiwa reformasi. Ketika reformasi dianggap sebagai salah satu celah yang potensial untuk memuluskan/ melancarkan tuntutan, maka warga Tawangmangu pun kembali aktif melanjutnya usahanya yang sempat terhenti.

Akhirnya, upaya yang telah dilakukan selama bertahun-tahun menuai hasil yang cukup menggembirakan. Pemerintah bersedia untuk menanggapi tuntutan masyarakat Tawangmangu tersebut dengan mengeluarkan berbagai kebijakan dan peraturan. Namun, kebijakan yang dikeluarkan oleh Pemerintah Provinsi Jawa Tengah tetap saja bernilai politis dan elitis serta merugikan warga Tawangmangu pemilik tanah persil. Bukannya meredakan konflik yang telah terjadi sejak lama, namun kebijakan pemerintah tersebut justru menimbulkan konflik baru dalam masyarakat. Puncaknya, warga Tawangmangu melancarkan berbagai aksi protes terhadap Pemerintah dan DPRD Jawa Tengah terkait kebijakan yang telah dikeluarkan tersebut. Aksi protes ini dilakukan bukan tanpa alasan yang jelas, mereka menganggap bahwa inilah jalan terakhir untuk memperjuangkan hak-hak mereka dalam meperoleh kembali tanah yang saat ini dikuasai oleh PPT setelah usaha diplomasi melalui negosiasi dan lobi gagal dilakukan selama bertahun-tahun.

Berbagai aksi protes yang dilakukan penduduk Tawangmangu pemilik tanah persil secara teoritis dapat dianalisis menggunakan Teori POST. Dalam political opportunity structure theory (POST) atau teori struktur kesempatan politik menjelaskan bahwa adanya kesempatan politik yang terbuka mendorong kelompok-kelompok gerakan sosial mempergunakannya sebagai sebuah momentum untuk melakukan penekanan untuk mencapai agenda gerakan sosialnya (Sidney Tarrow, 1998: 71 - 90). Teori POST menekankan bahwa gerakan sosial membesar disebabkan beberapa variabel dalam struktur kesempatan politik mengalami perubahan, yang mencakupi bentuk lembagalembaga politik di dalam masyarakat, perilaku para elite politik yang sedang menjabat, tingkat kontrol sosial dan penindasan terhadap gerakangerakan kemasyarakatan, serta adanya reduksi yang disengaja atau tidak sengaja terhadap tingkat kontrol sosial yang diterapkan untuk melawan sebuah gerakan (Robert Mirsel, 2004: 67). Misalnya, masyarakat memiliki kebebasan untuk berorganisasi, berkumpul, 
dan mengeluarkan pendapat di mana variabel-variabel ini tidak bisa dinikmati ketika rezim yang berkuasa menutup struktur kesempatan politik yang ada. Di samping itu, kelompok-kelompok gerakan sosial juga bisa mengakses pers dengan relatif mudah dan pers sendiri cukup berani dalam menyampaikan fakta-fakta dari lapangan.

Penduduk atau komunitas lokal Tawangmangu pemilik tanah persil melakukan protes-protes agraria ditujukan untuk beberapa hal. Pertama, mereka melawan untuk mempertahankan lahan yang mereka kuasai semenjak lama sebagai tempat pemukiman atau sebagai tempat melakukan aktivitas perekonomian yang diambil alih secara paksa oleh Negara. Hal ini terjadi karena pemerintah setempat (Pemerintah Provinsi Jawa Tengah) melakukan cara-cara penekanan untuk memaksakan kehendaknya, dan ini menyebabkan masyarakat Tawangmangu melakukan perlawanan untuk mempertahankan tanahnya.

Kedua, penduduk Tawangmangu memprotes Negara untuk menuntut apa yang mereka sebut sebagai haknya terhadap lahan dan tanah yang sedang dikontrol atau diolah oleh Negara atau bisnis. Penduduk Tawangmangu melawan aparatur Negara (Pemerintah Provinsi Jawa Tengah) karena tanah dan lahan yang dipersoalkan diyakini sebagai masih milik mereka dengan berbagai alasan, seperti tanah tersebut sejak dulu adalah lahan garapan mereka dan tanah tersebut merupakan tanah ulayat yang hak kepemilikannya masih ditangan mereka.

Ketiga, perlawanan penduduk Tawangmangu kepada aparatur Negara karena persoalan kompensasi harga pembebasan tanah yang ditetapkan oleh Pemerintah Provinsi. Alasan ketiga inilah yang belakangan menjadi faktor pendorong utama penduduk dalam melancarkan aksi protes kepada Pemerintah Provinsi. Ketika penduduk merasa bahwa usaha mereka selama ini dalam membebaskan tanah akan segera terwujud, Pemerintah Provinsi justru mengeluarkan berbagai kebijakan dan peraturan untuk mengulur proses pembebasan tanah. Hal inilah yang membuat konflik antara Pemerintah Provinsi dengan penduduk Tawangmangu semakin berkepanjangan, dan terlihat bahwa masing-masing pihak tetap berusaha mempertahankan tanah persil sebagai asetnya yang berharga.

Alasan-alasan yang dikemukakan di atas, merupakan faktor pendorong bagi penduduk Tawangmangu dalam melancarkan aksi protes kepada Pemerintah Provinsi Jawa Tengah. Berbagai protes agraria yang dilakukan oleh penduduk Tawangmangu tersebut terjadi pada masa pasca kemerdekaan, masa Orde Baru, hingga masa reformasi. 
Tabel 3.

Aktor-aktor Lokal Protes Agraria

Pasca Kemerdekaan - Masa Orde Baru di Tawangmangu

\begin{tabular}{|l|l|l|l|l|}
\hline \multicolumn{1}{|c|}{$\begin{array}{c}\text { Pelaku } \\
\text { Protes }\end{array}$} & Bentuk Protes & \multicolumn{1}{|c|}{ Tujuan } & \multicolumn{1}{c|}{ Tuntutan } & Keterangan \\
\hline $\begin{array}{l}\text { Organisasi } \\
\text { masyarakat }\end{array}$ & $\begin{array}{l}\text { Demonstrasi } \\
\text { massa }\end{array}$ & $\begin{array}{l}\text { Kantor } \\
\text { Gubenur dan } \\
\text { DPRD }\end{array}$ & $\begin{array}{l}\text { Status } \\
\text { kepemilikan } \\
\text { tanah persil } \\
\text { menjadi hak } \\
\text { milik } \\
\text { penduduk }\end{array}$ & $\begin{array}{l}\text { Anggota } \\
\text { masyarakat } \\
\text { yang } \\
\text { tergabung } \\
\text { dalam }\end{array}$ \\
HPTPT
\end{tabular}

Sumber: diolah dari berbagai sumber

Tabel 4.

Aktor-aktor Protes Agraria

Pasca Reformasi di Tawangmangu

\begin{tabular}{|c|c|c|c|c|}
\hline \multicolumn{2}{|c|}{ Pelaku Protes } & \multirow{2}{*}{$\begin{array}{l}\text { Bentuk } \\
\text { Protes }\end{array}$} & \multirow[t]{2}{*}{ Tuntutan } & \multirow[t]{2}{*}{ Tujuan } \\
\hline Internal & Eksternal & & & \\
\hline PWTPTP & LSM & $\begin{array}{l}\text { Demonstrasi } \\
\text { massa dan } \\
\text { dialog } \\
\text { interaktif } \\
\text { melalui RRI }\end{array}$ & $\begin{array}{l}\text { - Hibah atas } \\
\text { tanah persil } \\
\text { - Menolak } \\
\text { untuk } \\
\text { membayar } \\
\text { uang sewa }\end{array}$ & $\begin{array}{l}\text { - Pemerintah } \\
\text { Provinsi Jawa } \\
\text { Tengah } \\
\text { - Perusahaan } \\
\text { Pariwisata } \\
\text { Tawangmang } \\
\text { u }\end{array}$ \\
\hline НРТРТ & - & $\begin{array}{l}\text { Publikasi } \\
\text { melalui } \\
\text { media cetak } \\
\text { (Koran) }\end{array}$ & $\begin{array}{l}\text { - Hibah atas } \\
\text { tanah persil } \\
\text { atau } \\
\text { penurunan } \\
\text { harga } \\
\text { kompensasi } \\
\text { - Menolak } \\
\text { untuk } \\
\text { membayar } \\
\text { uang sewa }\end{array}$ & $\begin{array}{l}\text { - Pemerintah } \\
\text { Provinsi Jawa } \\
\text { Tengah } \\
\text { - Perusahaan } \\
\text { Pariwisata } \\
\text { Tawangmang } \\
\text { u }\end{array}$ \\
\hline НРТРТ & - & $\begin{array}{l}\text { Strategi Lobi } \\
\text { dengan } \\
\text { berkirim } \\
\text { surat }\end{array}$ & $\begin{array}{l}\text { - Penegakan } \\
\text { supremasi } \\
\text { hukum bagi } \\
\text { pemilik tanah }\end{array}$ & $\begin{array}{l}\text { - Badan } \\
\text { Pertanahan } \\
\text { Nasional } \\
\text { (BPN) Pusat }\end{array}$ \\
\hline
\end{tabular}


Konflik Agraria yang Tak Kunjung Usai

\begin{tabular}{|l|l|l|l|}
\hline & pengaduan & persil \\
masyarakat & & Menolak \\
& & membayar \\
& & uang \\
& & kompensasi & \\
\hline
\end{tabular}

Sumber: diolah dari berbagai sumber

Dalam Teori POST juga dikemukakan bahwa ada beberapa pilihan-pilihan strategis yang dapat dikembangkan, yaitu dengan membentuk sebuah organisasi baik terlembaga atau tidak terlembaga yang memiliki struktur yang mudah untuk dimobilisasi (Yudhie Haryono Muhammad, 2005: 107 113). Berdasarkan pemahaman mereka terhadap situasi yang terjadi, maka aksi-aksi yang dilakukan oleh komunitas lokal untuk menuntut hak-hak atas tanah miliknya yang diambil alih oleh Negara merupakan suatu respon yang kreatif, dan bukan sekedar respon-respon tanpa refleksi nyata. Strategi-strategi yang diterapkan oleh komunitas lokal di Tawangmangu dalam memperjuangkan pembebasan tanah persil dapat dibagi menjadi empat, yaitu: strategi organisasi, strategi lobi, strategi kekerasan, dan strategi demonstrasi. Pada prakteknya, mereka mengkombinasikan strategi-strategi tersebut dalam beberapa tahapan.

Saat ini penduduk Tawangmangu pemilik tanah persil terus diintimidasi pihak PPT untuk melakukan pembayaran kompensasi, baik secara tunai maupun angsuran. Namun, mereka tetap menolaknya bahkan terus berupaya memperjuangkan tanah persil dengan mengirimkan surat ke Badan Pertanahan Nasional (BPN) Pusat untuk memperoleh dukungan yang lebih besar. Dasar penolakan mereka ini dapat ditelusuri melalui bukti kepemilikan atau hak atas tanah yang dimiliki dengan dua hal. Pertama, hukum positif berdasarkan bukti-bukti tertulis. Kedua, klaim masyarakat yang bersifat sosiologis - antropologis berdasarkan pengetahuan masyarakat yang tidak tertulis. Setelah ditelusuri lebih lanjut, ternyata masyarakat Tawangmangu pemilik tanah persil memiliki kedua syarat tersebut yang dapat dijadikan bukti kepemilikan tanah. Untuk bukti-bukti tertulis, mereka memiliki bukti Pethuk Letter $C$ dan surat-surat keterangan lain yang dikeluarkan oleh pihak Kecamatan Tawangmangu. Sedangkan untuk syarat yang kedua, sejarah tentang kepemilikan tanah persil sudah lama hidup dan berkembang dalam masyarakat Tawangmangu. Meskipun mereka memiliki kedua bukti yang dapat dijadikan dasar untuk menjadikan tanah tersebut menjadi hak milik, namun mereka tetap saja kalah ketika berhadapan dengan Negara sebagai penguasa tunggal atas tanah yang ada di wilayahnya. 
Selain itu, masyarakat Tawangmangu juga memperoleh banyak dukungan dari berbagai pihak seperti: Bupati Karanganyar, DPRD Karanganyar, LSM, dan Keraton Mangkunegaran. Pemerintah Kabupaten Karanganyar turut memberikan dukungan dengan menjadi mediator dalam pertemuan antara masyarakat Tawangmangu pemilik tanah persil dengan Pemerintah Provinsi Jawa Tengah untuk membahas penyelesaian konflik tanah persil. Dukungan ini sebenarnya merupakan hal yang wajar, bahkan menjadi tanggung jawab Pemerintah Karanganyar untuk membantu warganya yang sedang menghadapi permasalahan. Alasan lain yang dapat dikemukakan bahwa Tawangmangu merupakan zona (kawasan) wisata andalan bagi Pemerintah Kabupaten Karanganyar, jadi apabila dalam masyarakat terjadi permasalahan yang dianggap krusial maka hal ini dapat mengganggu aktivitas pariwisata sehingga mempengaruhi pendapatan daerah.

\section{Resolusi Konflik yang dilakukan Pemerintah Provinsi Jawa Tengah}

Resolusi konflik diartikan sebagai suatu upaya menangani sebab-sebab konflik dan berusaha membangun hubungan baru dan yang bisa bertahan lama di antara kelompok-kelompok yang bermusuhan. Resolusi konflik ini mengacu pada strategi-strategi untuk menangani konflik terbuka dengan harapan tidak hanya mencapai suatu kesepakatan untuk mengakhiri kekerasan (penyelesaian konflik), tetapi juga mencapai suatu resolusi dari beberapa perbedaan sasaran yang menjadi penyebabnya (Simon Fisher, dkk. 2000: 7).

Berbagai aksi protes dan usaha-usaha lain yang dilakukan masyarakat pemilik tanah persil di Tawangmangu selama bertahuntahun untuk memperoleh status kepemilikan hak tanah memang membuahkan hasil, walaupun tidak terlalu memuaskan. Pemerintah Provinsi Jawa Tengah mengeluarkan kebijakan untuk melepaskan tanah tersebut dengan kompensasi, sehingga tuntutan yang dilakukan masyarakat pemilik tanah persil Tawangmangu mengalami perubahan. Tuntutan mereka kemudian setelah adanya kebijakan yang dikeluarkan Pemerintah Provinsi Jawa Tengah tersebut adalah menuntut agar pelepasan tanah tersebut dilakukan tanpa adanya kompensasi apa pun. Selain karena tidak mampu membayar uang kompensasi, mereka juga merasa tidak perlu membayar sejumlah uang kepada Pemerintah Provinsi Jawa Tengah dengan alasan bahwa sejak dulu tanah tersebut adalah milik penduduk Tawangmangu. Iuran yang harus dibayarkan kepada Negara hanyalah berupa PBB (Pajak Bumi dan Bangunan) dan bukan uang sewa atau uang kompensasi untuk pembebasan tanah.

Pemerintah Provinsi Jawa Tengah memang berencana menutup Perusahaan Pariwisata Tawangmangu (PPT) yang mengurusi permasalahan tanah 
persil di Tawangmangu. Karena selain maraknya aksi-aksi protes yang dilancarkan masyarakat Tawangmangu untuk membebaskan tanah persil yang berada di bawah kontrol PPT, dalam realisasinya Perusda ini (PPT) tidak mampu memenuhi target pendapatan yang telah ditetapkan oleh Pemerintah Provinsi Jawa Tengah. Rencana penutupan PPT ini disampaikan oleh Gubernur Jawa Tengah dalam Laporan Pertanggungjawaban/ Nota Keuangan Akhir Tahun Anggaran (TA) 2002. Dalam banyak artikel yang dibuat beberapa harian surat kabar lokal (Harian Joglosemar), diungkapkan bahwa Gubernur Jawa Tengah tidak ingin selalu dipusingkan oleh aksi-aksi protes yang dilakukan oleh masyarakat tanah persil Tawangmangu, maka ia pun mengambil langkah untuk mendiskusikan negosiasi harga yang sebelumnya telah ditetapkan oleh DPRD Jawa Tengah (Jum'at, 27 Agustus 2010).

Usaha yang dilakukan Pemprov merupakan jawaban atas berbagai kritik yang disampaikan DPRD Jawa Tengah tentang lambannya pemenuhan target pendapatan asli daerah (PAD) dari hasil penjualan tanah persil. Dengan demikian Pemprov menawarkan diskusi kepada para pemilik tanah persil untuk negosiasi ulang. Namun mereka tidak mau, meskipun sudah beberapa kali diundang pihak PPT dan Pemprov.

Ketika struktur politis tidak memberikan kesempatan/ peluang kepada komunitas pemilik tanah persil Tawangmangu untuk mempertahankan haknya, konflik agraria ini dimenangkan oleh Negara. Namun, ketika struktur politik makro berubah (era reformasi), maka peluang politik bagi masyarakat sipil akan terbuka sehingga masyarakat dapat menuntut haknya. Sama halnya dengan apa yang terjadi pada perjuangan yang dilakukan komunitas pemilik tanah persil Tawangmangu selama bertahuntahun, dimana terus mengalami pasang surut sesuai dengan situasi sosial politik yang terjadi pada masanya. Pihak yang pro berpendapat bahwa mengapa tanah tersebut tidak diberikan saja secara cuma-cuma kepada rakyat, karena mereka memang tidak memiliki kemampuan untuk membayar kompensasi tersebut. Sedangkan pihak yang kontra berpendapat bahwa tanah tersebut adalah asset Negara, jadi tidak dapat begitu saja diberikan kepada masyarakat secara cuma-cuma dan harus ada kompensasi jika ingin memilikinya.

Berdasarkan uraian di atas, dapat dilihat bahwa proses yang dilakukan sebagai langkah resolusi konflik lebih banyak bersifat top down, di mana penduduk Tawangmangu selaku pemilik tanah persil tidak dilibatkan dalam pengambilan kebijakan-kebijakan yang berhubungan dengan status kepemilikan tanah persil. Kebijakankebijakan yang dikeluarkan oleh Pemerintah Provinsi Jawa Tengah untuk diselanjutkan diberitahukan 
kepada penduduk Tawangmangu pemilik tanah persil melalui sosialisasi yang dilakukan oleh pihak Perusahaan Pariwisata Tawangmangu (PPT). Hasilnya tentu saja dapat dilihat, penduduk seringkali merasa tidak puas dan dengan kebijakan yang ada karena tidak mencerminkan prinsip-prinsip keadilan dan keberpihakan pada masyarakat kecil.

Perbedaan pandangan antara Pemerintah Provinsi Jawa Tengah dengan masyarakat pemilik tanah persil Tawangmangu dalam memperoleh status kepemilikan tanah setidaknya dapat digambarkan dalam bagan berikut ini:

Tabel 5.

Perbedaan Perspektif Tentang Tanah Persil Antara

Penduduk Tawangmangu dengan Pemerintah Provinsi Jawa Tengah

\begin{tabular}{|c|l|l|l|}
\hline No. & \multicolumn{1}{|c|}{ Aspek } & $\begin{array}{l}\text { Perpektif Penduduk } \\
\text { Tawangmangu }\end{array}$ & $\begin{array}{l}\text { Perspektif Pemprov. } \\
\text { Jawa Tengah }\end{array}$ \\
\hline 1. & $\begin{array}{l}\text { Cerita bahwa tanah } \\
\text { persil merupakan } \\
\text { tanah yang dibagikan } \\
\text { Keraton } \\
\text { Mangkunegaran } \\
\text { kepada penduduk } \\
\text { Tawangmangu }\end{array}$ & $\begin{array}{l}\text { Bukti bahwa } \\
\text { penduduk bisa } \\
\text { mendapatkan } \\
\text { sertifikat hak milik } \\
\text { atas tanah bekas } \\
\text { Swapraja tersebut }\end{array}$ & $\begin{array}{l}\text { Cerita itu diragukan } \\
\text { dan tidak bisa } \\
\text { dijadikan landasan } \\
\text { hukum bagi } \\
\text { penduduk untuk } \\
\text { dapat memilikinya }\end{array}$ \\
\hline 2. & $\begin{array}{l}\text { Letak atau posisi tanah } \\
\text { di dalam HPL }\end{array}$ & $\begin{array}{l}\text { HPL cacat, tidak } \\
\text { sesuai dengan realita } \\
\text { di lapangan }\end{array}$ & $\begin{array}{l}\text { HPL benar dan sah, } \\
\text { sudah sesuai } \\
\text { dengan prosedur } \\
\text { atau aturan }\end{array}$ \\
\hline 3. & $\begin{array}{l}\text { Anggapan bahwa } \\
\text { penduduk tinggal di } \\
\text { tanah HPL }\end{array}$ & $\begin{array}{l}\text { Tidak benar, tanah } \\
\text { itu adalah tanah } \\
\text { leluhur mereka sejak } \\
\text { dahulu }\end{array}$ & $\begin{array}{l}\text { Alasan agar dapat } \\
\text { menarik uang sewa }\end{array}$ \\
\hline 4. & $\begin{array}{l}\text { Penduduk wajib } \\
\text { membayar uang sewa }\end{array}$ & $\begin{array}{l}\text { Menolak karena } \\
\text { aturan itu dibuat } \\
\text { untuk kepentingan } \\
\text { penguasa }\end{array}$ & $\begin{array}{l}\text { Untuk } \\
\text { meningkatkan } \\
\text { pendapatan } \\
\text { Pemprov. }\end{array}$ \\
\hline 5. & $\begin{array}{l}\text { Keberadaan organisasi } \\
\text { masyarakat }\end{array}$ & $\begin{array}{l}\text { Wadah perjuangan } \\
\text { untuk } \\
\text { menyampaikan } \\
\text { tuntutan dan } \\
\text { memperoleh hak } \\
\text { milik atas tanah } \\
\text { persil }\end{array}$ & $\begin{array}{l}\text { Tidak mengakui, } \\
\text { karena merupakan } \\
\text { provokator untuk } \\
\text { menentang berbagai } \\
\text { kebijakan } \\
\text { Pemerintah }\end{array}$ \\
\hline
\end{tabular}


Konflik Agraria yang Tak Kunjung Usai

\section{Alternatif Resolusi Konflik Berbasis Rasa Keadilan}

Bercermin pada Teori

Keadilan yang dikemukakan oleh John Rawls, resolusi konflik atas sengketa tanah persil Tawangmangu belumlah mencerminkan prinsip-prinsip keadilan karena elemen masyarakat sipil (baik yang terorganisir maupun tidak) tidak dilibatkan dalam proses pengambilan keputusan. Prinsip keadilan yang menyatakan bahwa "setiap orang mempunyai hak yang sama atas kebebasan dasar yang paling luas, seluas kebebasan yang sama bagi semua orang" (John Rawls, 2006: 72) tidak berlaku bagi penduduk Tawangmangu pemilik tanah persil, meskipun hal tersebut berkaitan erat dengan institusi sosial utama yaitu kepemilikan privat atas alatalat produksi (berupa tanah).

Keadilan dalam skema sosial secara mendasar bergantung pada bagaimana hak-hak dan kewajiban fundamental diterapkan pada peluang ekonomi serta kondisi sosial dalam berbagai sektor masyarakat. Resolusi konflik yang ditawarkan Pemerintah Provinsi Jawa Tengah dalam menyelesaikan sengketa tanah persil ini rupanya belum mengedepankan prinsip keadilan bagi penduduk Tawangmangu pemilik tanah persil. Berdasarkan skema sosial yang ada, seharusnya penduduk Tawangmangu pemilik tanah persil dapat ikut menentukan resolusi konflik karena hal itu merupakan haknya. Hal itu karena institusi sosial utama tersebut (kepemilikan privat atas alat-alat produksi, berupa tanah) dapat mempengaruhi prospek kehidupan mereka, seperti: apa yang bisa mereka harapkan dan seberapa bisa mereka mengharapkannya. Bila penduduk gagal mempertahankan tanah yang sejak lama digarap dan dihuni, maka hal itu dapat berpengaruh pada aktivitas ekonomi mereka. Tanah merupakan sumber kehidupan mereka, karena di sanalah mereka mengusahakan berbagai jenis pertanian mulai dari menanam sayuran, buahan, hingga bunga yang hasilnya dijual untuk memenuhi berbagai kebutuhan hidup. Jadi dapat diprediksi, apabila mereka tidak mampu membayar kompensasi yang ditetapkan oleh Pemerintah, maka mereka akan kehilangan tanah tersebut dan kehilangan mata pencaharian. Untuk itulah mereka menolak kompensasi yang telah diputuskan DPRD Jawa Tengah dalam Rapat Paripurna sebagai resolusi konflik atas sengketa tanah persil Tawangmangu.

Dalam institusi terdapat sistem aturan publik yang menentukan jabatan serta posisi dengan hak dan kewajiban tertentu, kekuatan dan kekebalan, dan lainlain. Aturan-aturan ini menggolongkan bentuk-bentuk tindakan yang diperbolehkan dan yang dilarang; dan memberikan hukuman serta pembelaan tertentu ketika pelanggaran terjadi (John Rawls, 2006: 66). Sama halnya dengan apa yang terjadi dalam 
sengketa tanah persil

Tawangmangu. Pemerintah

Provinsi Jawa Tengah sebagai penguasa atas tanah-tanah yang berada di wilayahnya merasa memiliki kekuatan untuk menentukan solusi atas berbagai masalah yang terjadi. Berbagai keputusan pun dikeluarkan sebagai solusi, meskipun dalam pelaksanaannya terjadi banyak pelanggaran. Ketika penduduk lokal mempermasalahkan pelanggaran yang dilakukan oleh aparat pemerintah maka dengan kekuatan dan kekebalan yang dimiliki, pelanggaran itu pun dianggap legal. Respon penduduk lokal tidak berhenti disitu saja. Mereka melakukan berbagai protes dan boikot sebagai bentuk hukuman yang patut diterima oleh Pemerintah.

Dengan demikian, resolusi ala Pemerintah itu seringkali terkesan jauh dari rasa keadilan dan terkesan mengedepankan kepentingan Pemerintah Provinsi Jawa Tengah (eksekutif dan legislatif). Telah ditunjukkan dalam uraian di atas bahwa ada persoalan ketidakadilan dalam proses pengontrolan tanah persil oleh Pemerintah Provinsi Jawa Tengah. Di samping itu, pengontrolan Pemprov atas tanah yang dipersoalkan secara hukum bermasalah. Untuk memecahkan permasalahan ini, Undang-undang memerintahkan kepada Pemerintah untuk mengkonversi tanah-tanah tersebut menjadi hak milik penduduk/ komunitas lokal. Ironisnya, Pemerintah setempat justru menguasai tanah-tanah tersebut dengan HPL (Hak Pengelolaan Lahan) yang dikeluarkan oleh Badan Pertanahan Nasional (BPN). Semestinya tanahtanah tersebut menjadi hak milik penduduk sejak lama, apabila Pemerintah memang benar-benar berpihak kepada penduduk/ komunitas lokal. Jadi, tidaklah mengherankan bila berbagai resolusi konflik yang telah dilakukan oleh Pemerintah Provinsi dan DPRD Jawa Tengah tidak mampu untuk menyelesaikan konflik agraria di Tawangmangu.

Dalam prinsip keadilan butir kedua yang dikemukakan oleh John Rawls (2006: 72) disebutkan bahwa "ketimpangan sosial dan ekonomi mesti diatur sedemikian rupa sehingga (1) dapat diharapkan memberi keuntungan semua orang, dan (2) semua posisi dan jabatan terbuka bagi semua orang". Bila diterapkan pada resolusi konflik atas sengketa tanah persil Tawangmangu, maka dapat dipahami bahwa untuk meningkatkan kesejahteraan penduduk diperlukan resolusi konflik yang berbasis pada rasa keadilan. Hal ini dapat dilakukan dengan melepas tanah-tanah persil yang berada di bawah kontrol Pemerintah Provinsi Jawa Tengah tanpa kompensasi apapun bagi penduduk lokal Tawangmangu. Dengan demikian, penduduk dapat mengusahakan/ menggarap tanahnya tanpa beban apapun sehingga memperoleh hasil yang lebih maksimal dan kesejahteraan pun meningkat. Di sisi lain, Pemerintah Provinsi Jawa Tengah dapat kerjasama dengan penduduk lokal untuk melakukan berbagai 
| Konflik Agraria yang Tak Kunjung Usai

upaya renovasi dan menambah fasilitas penunjang objek wisata agar jumlah kunjungan wisata meningkat, sehingga dapat meningkatkan PAD (Pendapatan Asli Daerah).

Pada intinya, resolusi konflik berbasis pada rasa keadilan mengedepankan partisipasi penduduk lokal dalam setiap proses pengambilan keputusan dan memperkecil ketimpangan sosial ekonomi dalam masyarakat. Bila prinsip ini diterapkan dalam resolusi konflik tanah persil Tawangmangu, dengan mengikutsertakan penduduk Tawangmangu pemilik tanah persil dalam setiap proses pengambilan keputusan, maka hasil yang diperoleh setidak-tidaknya seperti apa yang digambarkan oleh Diana Francis dan Guus Meyer (dalam Simon Fisher, dkk., 2000: 121) berikut ini:

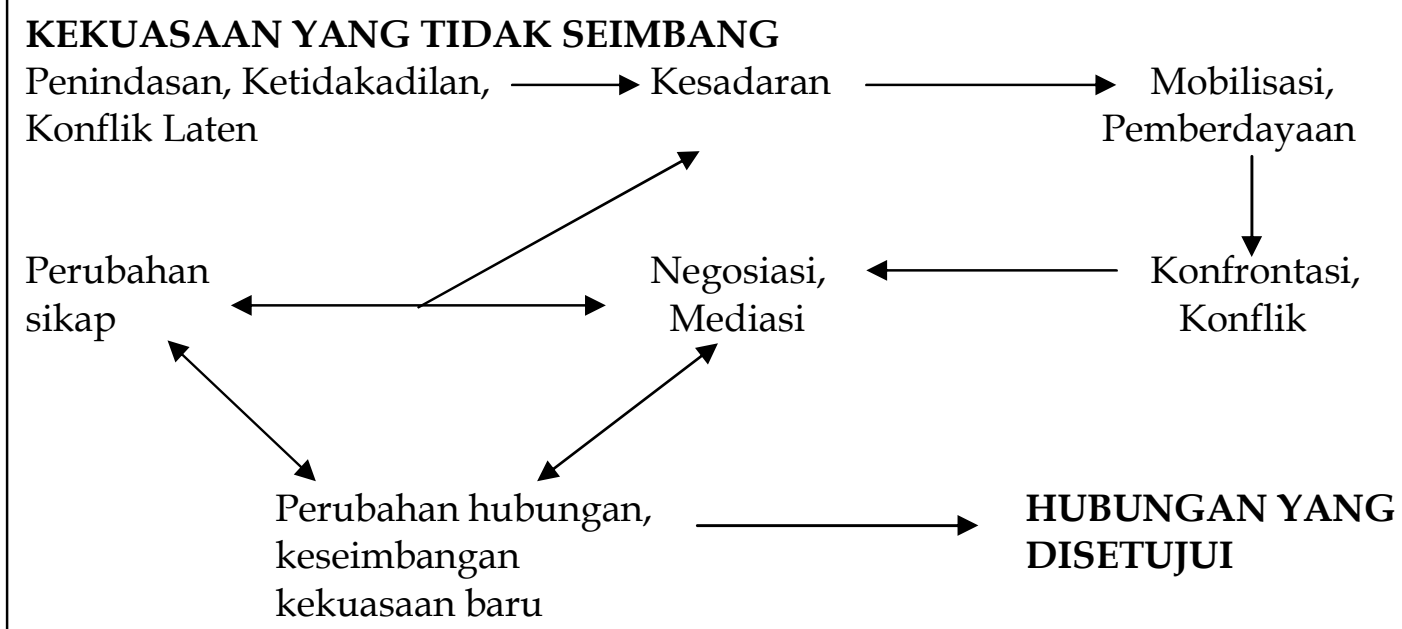

KEKUASAAN YANG SEIMBANG

Bagan 1.

Menyeimbangkan Kekuasaan

Untuk lebih memperkuat
resolusi konflik yang telah
diuraikan di atas, secara hukum ada
beberapa faktor yang dapat
mendukung kebenaran resolusi
yang diajukan. Menurut Jeferson
Kameo, SH, LLM, PhD (dalam
http://m.suaramerdeka.com),
apabila kasus tanah persil
Tawangmangu dibedah dengan
kaidah pendaftaran tanah,

ditemukan prinsip hukum dalam hukum tanah di Republik Indonesia. Intinya menegaskan dalam hal tidak atau tidak ada lagi tersedia secara lengkap alat-alat pembuktian (surat-surat), maka pembuktian hak dapat dilakukan berdasarkan kenyataan penguasaan fisik tanah yang bersangkutan selama lima tahun atau lebih secara berturut-turut dengan itikad baik 
secara terbuka. Artinya, dalam kasus tanah persil Tawangmangu, ketentuan ini menegaskan dengan jelas bahwa Pemerintah Provinsi Jawa Tengah tidak perlu lagi merasa berhak atas tanah tersebut. Ia telah kehilangan HPL-nya tanpa hibah atau bentuk peralihan hak konvensional lainnya.

Apabila kesempatan ini tidak diambil lebih dari lima tahun (dalam hal ini oleh pihak Pemprov yang merasa dapat membuktikan sesungguhnya ia pemilik dari tanah yang bersangkutan), maka Pemprov dianggap telah lalai; suatu perbuatan melawan hukum. Pemprov melakukan suatu pembiaran atas penguasaan terhadap properti miliknya. Apabila jangka waktu lewat (mora), maka berlakulah rei interventus. Maksudnya, kekuasaan untuk berubah pendirian (resling) menurut hukum sesudah terhalangi dengan tindakan-tindakan pembiaran.

Untuk penyelesaiannya (secara hukum), kemudian membebani pihak Pemprov yang telah membiarkan rakyat secara beritikad baik dan terbuka menguasai hak tanah rakyat dalam preskripsi lima tahun dengan kewajiban untuk memberikan ganti kerugian, bukan justru sebaliknya, memaksakan ganti rugi dari rakyat. Pemahaman hukum seperti yang baru saja dikemukakan harus ada dalam rangka meniadakan atau setidak-tidaknya mengurangi problematika konflik pertanahan di Tanah Air.

\section{Catatan Penutup}

Berbicara mengenai konflik agraria dan protes komunitas lokal, maka kita pelu melihatnya dari aspek historis bagaimana proses perubahan hak atas tanah penduduk itu terjadi dan dimensi apa saja yang mempengaruhinya, baik itu dimensi ideologi, politik, ekonomi, maupun dimensi kepentingan lainnya yang mempengaruhi proses transformasi tanah-tanah penduduk lokal.

Logika pembangunan ekonomi dan sistem yang terpusat telah membuat negara membentuk alat-alat kekuasaannya, seperti hukum dan aparat keamanan untuk memaksa penduduk supaya tunduk dan patuh tanpa diberikan pilihan sama sekali. Penduduk lokal harus menerima keputusan sepihak para penguasa apabila ingin memperoleh hak milik atas tanah yang telah dihuni dan digarap dengan membayar uang (dalam jumlah yang besar) kepada Pemerintah sebagai kompensasinya. Ketentuan Undang-undang atau hukum, kebanyakan tidak memihak kepada kepentingan penduduk lokal bahkan sering memojokkannya, misalnya karena tidak ada buktibukti positif seperti sertifikat, bukti ahli waris, atau lainnya. Meskipun penduduk lokal memiliki Pethuk Letter $\mathrm{C}$ yang sejak dulu dijadikan bukti kepemilikan tanah, namun dasar itu dianggap tidak sah dan tidak mememuhi kriteria/ syarat yang diatur dalam Undang-undang atau Ketetapan Pemerintah lainnya. Selain hal-hal tersebut, logika untuk kepentingan negara juga sering dijadikan alasan untuk mengambil tanah penduduk, baik itu secara paksa melalui militer atau melalui manipulasi kebijakan negara. 
Paradigma negara dengan menguasai semua aspek yang ada dan untuk kesejahteraan rakyat ternyata pada realitanya justru terbalik, penduduk malah menjadi sengsara, menderita, dan miskin karena telah kehilangan tanahnya yang merupakan sumber untuk kehidupan mereka. Keadaan yang seperti ini telah membuat masyarakat sadar dan bersatu untuk kemudian melakukan perlawanan demi kembalinya tanah-tanah mereka yang dulu mereka miliki.

Sama halnya dengan apa yang terjadi di Tawangmangu. Yang dapat kita pelajari adalah konflik agraria di Tawangmangu tersebut merupakan perlawanan komunitas lokal terhadap ketidakadilan yang mereka rasakan, dan oleh sebab itu, mereka menuntut penyelesaian yang adil pula. Konflik yang terjadi memperlihatkan problema pluralisme hukum agraria di Indonesia. Tanah-tanah yang disengketakan adalah bekas Swapraja Mangkunagaran yang menurut UUPA 1960 diambil alih oleh negara sehingga menjadi tanah negara dan selanjutnya dapat dikonversi menjadi hak milik individu penduduk lokal yang telah lama menghuni dan menggarapnya. Namun yang terjadi tidaklah demikian. Negara (dalam hal ini Pemerintah Provinsi Jawa Tengah) justru membuat berbagai kebijakan/ ketetapan baru untuk menyelesaikan konflik agraria yang terjadi di Tawangmangu. Kebijakan/ ketetapan yang ada justru menguntungkan Pemerintah dan jelas merugikan penduduk lokal sehingga menimbulkan reaksi negatif dari masyarakat yaitu dengan menolak keputusan yang telah dikeluarkan oleh Pemerintah Provinsi Jawa Tengah.

Berdasarkan resolusi konflik atas sengketa tanah persil tawangmangu yang telah didiskusikan memperlihatkan bahwa resolusi yang ditawarkan oleh Pemerintah Provinsi Jawa Tengah tidak adil. Hukum agraria yang ada yang menjadi dasar pemerintah menyelesaikan konflik tersebut merupakan keputusan sepihak Pemerintah yang jauh dari rasa keadilan, karena tidak mempertimbangkan partisipasi penduduk Tawangmangu pemilik tanah persil dalam proses resolusi konflik. Dengan demikian, konflik belum selesai dan tidak menutup kemungkinan di kemudian hari penduduk Tawangmangu pemilik tanah persil kembali melakukan berbagai protes-protes agraria guna menuntut resolusi konflik yang berbasis pada rasa keadilan.

$\begin{array}{llr}\text { Untuk } & \text { itulah, } & \text { diperlukan } \\ \text { resolusi } & \text { konflik } & \text { yang } \\ \text { mengikutsertakan } & \text { partisipasi } \\ \text { penduduk } & \text { lokal } & \text { guna }\end{array}$
mengakomodasi kepentingan mereka agar konflik tersebut dapat diselesaikan dan keadilan sosial dapat berpihak pada penduduk/ komunitas lokal yang telah lama menghuni dan menggarap tanah persil tersebut. Berikut ini akan dikemukakan beberapa hal yang mungkin dapat dijadikan bahan 
masukan bagi penyelesaian konflik agraria di Tawangmangu:

1. Besarnya kompensasi yang telah ditetapkan dalam Rapat Paripurna DPRD Jawa Tengah hendaknya ditinjau kembali. Hal ini didasarkan pada penolakan penduduk lokal atas keputusan yang dikeluarkan oleh DPRD Jawa Tengah tersebut. Bila keputusan ini dijalankan, maka penduduk lokal yang umumnya bekerja di sektor pertanian berskala kecil harus membayar uang sekitar Rp 200 juta rupiah kepada Pemerintah Provinsi Jawa Tengah untuk memperoleh sertifikat hak milik tanah.

2. Jika Pemerintah Provinsi Jawa Tengah ingin berpihak pada masyarakat kecil, sebenarnya dapat saja melepaskan tanah-tanah persil kepada penduduk lokal tanpa harus ada kompensasi apa pun karena hal ini ditujukan untuk kesejahteraan penduduk.

Dengan demikian, diharapkan konflik agraria yang telah berjalan selama bertahuntahun dapat selesai dengan resolusi konflik yang didasarkan pada prinsip-prinsip keadilan sosial bagi penduduk lokal.

\section{Daftar Pustaka}

Joglosemar. Kasus Tanah Persil Gubernur Masih Buka Negosiasi Harga. 27 Agustus 2010.
Jeferson Kameo. 31 Mei 2010. Hak Tanah Rakyat. Tersedia di: http://m.suaramerdeka.com

John Rawls. 2006. Teori Keadilan. Yogyakarta: Pustaka Pelajar.

Poerwanti Hadi Pratiwi. 2007. Sengketa Agraria Di Era Reformasi (Studi tentang Kasus Tanah Persil di Kecamatan Tawangmangu, Kabupaten Karanganyar, Provinsi Jawa Tengah). Tesis. Yogyakarta: Sekolah Pascasarjana Universitas Gadjah Mada.

Rbert Mirsel. 2004. Teori Pergerakan Sosial: Kilasan Sejarah dan Catatan Bibliografis. Yogyakarta: Resist Book.

Sidney Tarrow. 1998. Power in Movement: Social Movement and Contentious Politics. $2^{\text {nd }}$ ed. United Kingdom: Cambridge University Press.

Simon Fisher, dkk. 2000. Mengelola Konflik: Keterampilan dan Strategi untuk Bertindak. United Kingdom: Zed Books.

Yudhie Haryono Muhammad. 2005. Hijrah Politik, Kitab Panduan Untuk Perubahan Fundamental: Dari Gerakan Mahasiswa, Gerakan Keagamaan, Gerakan Lingkungan, dan Gerakan Adat ke Gerakan Politik. Jakarta: PTIK Press - Restu Agung. 